\title{
SEBARAN SPASIAL DAN TEMPORAL FENOL, KROMIUM DAN MINYAK DI SEKITAR SENTRA INDUSTRI BATIK KABUPATEN PEKALONGAN
}

\author{
Yustiara Widya Saraswati, Haeruddin ${ }^{1}$, Frida Purwanti \\ Program Studi Manajemen Sumberdaya Perairan, Jurusan Perikanan \\ Fakultas Perikanan dan Ilmu Kelautan, Universitas Diponegoro
}

\begin{abstract}
Abstrak
Penelitian ini bertujuan untuk mengetahui konsentrasi fenol, kromium dan minyak serta sebarannya secara spasial dan temporal di sekitar sentra industri batik dalam air Sungai Bremi Kabupaten Pekalongan. Penelitian ini dilaksanakan pada bulan Mei-Juni 2013 di Sungai Bremi Kabupaten Pekalongan. Metode yang digunakan dalam penelitian ini adalah metode survei, sedangkan pengambilan sampel menggunakan metode composite sample yang merupakan penggabungan sampel air agar mendapatkan sampel sehomogen mungkin sehingga sampel dapat mewakili kualitas perairan sesungguhnya. Penelitian ini menggunakan materi air Sungai Bremi dan data citra Landsat 8 Jawa Tengah, materi utama adalah air Sungai Bremi yang kemudian dilihat konsentrasi dari fenol, kromium dan minyak yang terdapat pada sampel. Sebaran spasial dari konsentrasi fenol, kromium dan minyak dapat dilihat menggunakan ER-Mapper 7.0. Pengambilan sampel dilakukan di 3 stasiun, dimana pada setiap stasiun terdapat 3 titik sampling

Hasil penelitian konsentrasi fenol Sungai Bremi bulan Mei dan Juni berkisar antara 0-0,031 mg/l, konsentrasi kromium 0,0005 mg/l dan konsentrasi minyak bulan Mei dan Juni berkisar antara 3,6-23,6 mg/l. Sebaran spasial dan temporal fenol tertinggi bulan Mei terdapat pada stasiun 1 sedangkan sebaran spasial dan temporal tertinggi fenol bulan Juni di stasiun 2. Sebaran spasial dan temporal minyak tertinggi bulan Mei dan Juni terdapat pada stasiun 3, sedangkan sebaran spasial dan temporal kromiun dikatakan konstan karena konsentrasi tiap titiknya sama.
\end{abstract}

Kata Kunci: Sebaran Spasial, Temporal, Fenol, Kromium, Minyak, Limbah Batik, Sungai Bremi.

\section{Abstract}

The purpose of the study were to determine location of the concentration, and spatial and temporal distribution of batik waste on Bremi River. The research was conducted in the Bremi River of Pekalongan Regency on May-June 2013. The method used in this research was a survey method, while sampling used a composite sampling method in which the water samples incorporated in order to obtain as homogeneous samples as possible so that the samples can represent the actual water quality. The materials of this study are the water of the Bremi River and Landsat 8 data image of Central Java, the main material is water of Bremi River to be it's seen concentrations of phenol, chromium and oil contained in the samples. The spatial distribution of concentration of phenol, chromium and oil can be seen using ER-Mapper 7.0. Sampling were done in 3 stations, 3 sampling point at each station.

The results of phenol concentration of Bremi River in May and June ranged from 0-0,031 mg/l, concentration of chromium $0,0005 \mathrm{mg} / \mathrm{l}$ and the concentration of oil ranged from 3,6-23,6 mg/l. The highest spatial and temporal distribution of phenol in May at station 1 while the highest spatial and temporal distribution of phenol in June at station 2. The highest spatial and temporal distribution of oil in May and June at station 3, while the spatial and temporal distribution of chromium are constant because concentration in every point is same.

Keywords: Spatial Distribution, Temporal, Phenol, Chromium, Oil, Batik Waste, Bremi River. 


\section{PENDAHULUAN}

Sungai Bremi masih termasuk dalam kawasan wilayah Kabupaten Pekalongan dan merupakan percabangan dari Sungai Sengkarang. Sungai Bremi mengaliri bebrapa wilayah yang padat penduduk dengan sebagian besar mata pencahariannya sebagai pengrajin batik atau buruh batik. adanya home industry batik di kawasan Kabupaten Pekalongan ini dapat memajukan kesejahteraan masyarakat sekitar Sungai Bremi, namaun bagi lingkungan khususnya perikanan dan perairan adanya home industry dapat menurunkan dan mengganggu stabilitas dari ekosistem sungai. Limbah dari proses membatik dapat bersifat toksik bagi perairan khususnya Sungai Bremi karena pada proses pembuatannya banyak menggunakan zat-zat kimia.

Menurut Wardhana (2004), Zat warna banyak dipakai dalam industri. Tanpa memakai zat warna hasil atau produk industri tidak menarik. Pada dasarnya semua zat warna adalah racun bagi tubuh manusia. Menurut Suharto (2011), zat warna tekstil yang digunakan berasal dari zat warna asam/basa, kationik, disperie, sulfur, kromofon dan kromagen. Pada proses pembuatan tekstil yang dihasilkan limbah cair dari pabrik tekstil berisi logam berat salah satunya adalah kromium. Fenol di dalam industri tekstil banyak digunakan sebagai pelarut pewarna kain. Pada proses pewarnaan, kain dicelup dalam pewarna sintetik (azodyes) dan obat-obatan lainnya. Salah satu turunan senyawa fenol yang digunakan dalam senyawa zat pewarna tekstil antara lain: 2-acetyl-amino phenol, 4-cloro-2-amino phenol. Senyawa fenol inilah yang berbahaya bagi makhluk hidup apalagi langsung dibuang ke lingkungan (Ulya, 2012). Pada proses pelorodan atau perebusan untuk menghilangkan malam pada kain menghasilkan limbah cair yang mengandung fenol dan minyak.

Tujuan dari penelitian ini adalah untuk mengetahui konsentrasi fenol, kromium dan minyak serta sebarannya secara spasial dan temporal di sekitar sentra industri batik dalam air Sungai Bremi Kabupaten Pekalongan.

\section{MATERI DAN METODE PENELITIAN}

\section{A. Materi Penelitian}

Materi yang digunakan dalam penelitian adalah sampel air yang telah terkontaminasi buangan limbah batik Sungai Bremi Kabupaten Pekalongan, data konsentrasi fenol, kromium, minyak dan data citra satelit LANDSAT 8 Jawa Tengah (30 Agustus 2013).

\section{B. Metode Penelitian}

Metode yang digunakan adalah metode survei. Menurut Arikunto (2006), Metode survei digunakan untuk mengumpulkan dan mendapatkan data sebanyak-banyaknya mengenai faktor-faktor pendukung dari tempat tertentu yang alamiah (bukan buatan), tetapi peneliti melakukan perlakuan dalam pengumpulan data, misalnya dengan mengedarkan kuesioner, test, wawancara terstruktur dan sebagainya.

\section{Metode Sampling}

Sampel air diambil menggunakan ember, pengambilan sampel dilakukan dengan cara gabungan (composite sample) yang kemudian disimpan dalam botol sampel. Menurut Haidi (2005) composite sample adalah sampel gabungan yang merupakan campuran dua atau lebih sampel sesaat ke dalam sebuah wadah untuk diuji di laboraturium. Pengambilan sampel gabungan ini dilakukan untuk mendapatkan sampel sehomogen mungkin sehingga sampel dapat mewakili kualitas lingkungan sesungguhnya. Air diambil dengan menggunakan gayung sedalam $\pm 1 \mathrm{~m}$ dari permukaan sungai. Pengambilan sampel air dilakukan dua kali dengan waktu yang berbeda berdasarkan waktu pembuangan limbah batik pada bulan Mei dan Juni. Air sampel yang telah di composite dimasukkan ke dalam botol sampel dan di simpan dalam cool box. Air sampel yang telah diambil akan diuji kandungan fenol, kromium dan minyak yang berasal dari buangan limbah Sungai Bremi. Selang sehari, semua sampel yang telah diawetkan menggunakan es batu atau disimpan dalam cool box kemudian dibawa ke laboratorium untuk dianalisa kandungan dari sampel-sampel tersebut. Data lapangan yang diambil antara lain adalah temperatur air, temperatur udara, kecerahan, $\mathrm{pH}$ dan kecepatan arus.

\section{Analisa Sebaran Spasial dan Temporal}

Analisis sebaran spasial dan temporal dikerjakan menggunakan software ER-Mapper 7.0 dengan cara membuat gridding yang kemudian overlay data sehingga dapat dilihat persebarannya.

\section{a. Plotting titik koordinat}

Plotting titik koordinat bertujuan untuk mengetahui lokasi pengambilan sampel serta mengubah format titik koordinat yang didapat dari GPS (Derajat, Menit, Detik) menjadi derajat desimal, karena pada pengolahan selanjutnya di software ER-Mapper 7.0, harus menggunakan titik koordinat dengan format derajat desimal. Proses plotting ini menggunakan software Google Earth. 


\section{b. Gridding}

Gridding bertujuan untuk mengetahui sebaran titik koordinat beserta nilai konsentrasi yang diteliti. Data yang digunakan pada proses gridding ini adalah titik koordinat (derajat desimal) dengan konsentrasi fenol, kromium dan minyak. Proses gridding hingga proses pembuatan layout menggunakan software ERMapper 7.0, kemudian hasil dari proses gridding ini selanjutnya akan di-overlay dengan data Landsat JawaTegah yang telah di-cropping. Pembuatan gridding sesuai dengan konsentrasi, titik koordinat dan waktu pengambilan sampel untuk membedakan sebaran spasial dan temporal.

\section{c. Cropping (Pemotongan citra)}

Pemotongan citra bertujuan untuk menyesuaikan ukuran citra dan membatasi wilayah pengamatan dengan objek yang akan dikaji. Data Landsat Jawa Tengah dipotong sesuai dengan lokasi penelitian yaitu wilayah Kabupaten Pekalongan.

\section{d. Overlay}

Overlay dilakukan dengan membandingkan kedua data yang ada dan telah diolah. Tujuan dilakukan overlay untuk melihat apakah ada suatu perubahan atau perbedaaan antara data satu dengan data yang lainnya. Data yang di-overlay pada penelitian ini adalah data hasil gridding dan data Landsat Jawa Tengah yang telah di-cropping.

\section{e. Pembuatan Layout}

Pembuatan layout peta hasil pengolahan data yang dilakukan padasoftware ER Mapper 7.0 bertujuan untuk memperjelas dan memberi tampilan peta beserta data-data yang tercakup di dalamnya. Hasil yang didapat kemudian ditampilkan dalam bentuk peta sebarannya.

\section{HASIL DAN PEMBAHASAN}

\section{Gambaran umum lokasi sampling}

Salah satu sungai di Kabupaten Pekalongan yang menjadi saluran pembuangan limbah batik adalah Sungai Bremi. Sungai Bremi berasal dari saluran pembuangan irigasi pada bagian hulu yang masuk ke dalam administratif Kabupaten Pekalongan. Alur sungai ini juga melintasi wilayah Kotamadya Pekalongan yang padat. Sungai Bremi merupakan anak sungai dari Sungai sengkarang dan diduga memiliki telah tercemar oleh limbah dari industri batik.. Beberapa desa yang pembuangan airnya dipengaruhi oleh Sungai Bremi diantaranya Kelurahan Pabean, Bandengan dan Keraton di Kecamatan Pekalongan Utara, Kelurahan Pasar Sari, Tirto, Bumirejo dan Kramat Sari di Kecamatan Pekalongan Barat. Pengambilan sampel air Sungai Bremi dibagi dalam tiga tempat, yaitu stasiun I di Desa Jenggot, stasiun II di Desa Pasirsari dan stasiun III di Desa Jeruksari. Posisi koordinat dari ketiga stasiun pengambilan sampel air Sungai Bremi tersaji dalam Tabel 1. Sebagai berikut:

Tabel 1. Posisi Koordinat Pengambilan Sampel di Sungai Bremi

\begin{tabular}{cccc}
\hline \multirow{2}{*}{ Stasiun } & \multirow{2}{*}{$\begin{array}{c}\text { Sub. } \\
\text { Stasiun }\end{array}$} & Lintang Selatan & Posisi Koordinat \\
\hline \multirow{2}{*}{ I } & 1.1 & $06^{\mathrm{O}} 55^{\prime} 3.09^{\prime}$, & Bujur Timur \\
\cline { 3 - 4 } & 1.2 & $06^{\mathrm{O}} 55^{\prime} 3.11^{\prime}$, & $109^{\mathrm{O}} 40^{\prime} 8.22^{\prime}$, \\
\multirow{2}{*}{ II } & 1.3 & $06^{\mathrm{O}} 55^{\prime} 3.13^{\prime}$, & $109^{\mathrm{O}} 40^{\prime} 8.12^{\prime}$, \\
& 2.1 & $06^{\mathrm{O}} 53^{\prime} 8.80^{\prime}$, & $109^{\mathrm{O}} 40^{\prime} 8.94^{\prime}$, \\
& 2.2 & $06^{\mathrm{O}} 53^{\prime}, 8.88^{\prime}$, & $109^{\mathrm{O}} 39^{\prime} 22.04^{\prime}$, \\
\multirow{2}{*}{ III } & 2.3 & $06^{\mathrm{O}} 53^{\prime}, 8.92^{\prime}$, & $109^{\mathrm{O}} 39^{\prime} 22.98^{\prime}$, \\
& 3.1 & $06^{\mathrm{O}} 51^{\prime} 34.40^{\prime}$, & $109^{\mathrm{O}} 39^{\prime} 22.88^{\prime}$, \\
& 3.2 & $06^{\mathrm{O}} 51^{\prime} 34.31^{\prime}$, & $109^{\mathrm{O}} 39^{\prime} 18.30^{\prime}$, \\
& 3.3 & $06^{\mathrm{O}} 51^{\prime} 34.23^{\prime}$, & $109^{\mathrm{O}} 39^{\prime} 18.84^{\prime}$, \\
\hline
\end{tabular}

Sumber pencemar yang terdapat di aliran Sungai Bremi Kabupaten Pekalongan diduga berasal dari limbah kegiatan produksi industri batik dan limbah domestik. Sumber limbah batik berada pada sepanjang aliran stasiun 1 dan stasiun 2. Letak dari sumber pencemar terbanyak berada pada stasiun 2. Stasiun 2 merupakan kawasan Kecamatan Tirto yang mencakup beberapa desa, antara lain adalah Desa Jeruksari dan Desa Pasirsari. Pengambilan sampel pada stasiun 2 yang terletak di Desa Pasirsari diduga merupakan sumber pencemar limbah batik terbanyak. Sepanjang pinggir sungai yang melewati Desa Pasirsari terdapat industri batik rumahan dengan warna air hitam pekat dan berbau tidak sedap.

Menurut penuturan warga sekitar, pembuangan limbah batik dilakukan seminggu sekali pada malam hari. Para pengrajin batik mengaku tidak memiliki IPAL untuk menampung air limbah dari proses membantik. Limbah batik tersebut langsung dibuang ke dalam sungai tanpa melalui proses terlebih dahulu, bahkan ada yang mencuci langsung batiknya di sungai. 


\section{Konsentrasi Fenol, Kromium dan Minyak}

Tabel 2. Konsentrasi Fenol (mg/l), Kromium (mg/l) dan Minyak (mg/l) di Sekitar Sentra Industri Batik dalam Air Sungai Bremi Kabupaten Pekalongan

\begin{tabular}{cccccccc}
\hline \multirow{2}{*}{ No. } & Parameter & \multicolumn{3}{c}{ Bulan Mei } & \multicolumn{3}{c}{ Bulan Juni } \\
\cline { 3 - 7 } & & St. 1 & St.2 & St.3 & St.1 & St.2 & St.3 \\
\hline 1 & \multirow{3}{*}{ Fenol } & 0,028 & 0,007 & 0,009 & 0,003 & 0,004 & 0,00 \\
& & 0,030 & 0,004 & 0,00 & 0,016 & 0,009 & 0,015 \\
& & 0,031 & 0,000 & 0,02 & 0,007 & 0,027 & 0,01 \\
2 & $0,0005^{*}$ & $0,0005^{*}$ & $0,0005^{*}$ & $0,0005^{*}$ & $0,0005^{*}$ & $0,0005^{*}$ \\
& \multirow{3}{*}{ Kromium Valensi 6} & $0,0005^{*}$ & $0,0005^{*}$ & $0,0005^{*}$ & $0,0005^{*}$ & $0,0005^{*}$ & $0,0005^{*}$ \\
& & $0,0005^{*}$ & $0,0005^{*}$ & $0,0005^{*}$ & $0,0005^{*}$ & $0,0005^{*}$ & $0,0005^{*}$ \\
& & 5.2 & 8 & 10.4 & 5.6 & 7.6 & 13.6 \\
& \multirow{3}{*}{ Minyak } & 6 & 13.5 & 16.8 & 4.4 & 16.4 & 21.2 \\
& & 8 & 9.2 & 12.4 & 3.6 & 23.6 & 14.8 \\
\hline
\end{tabular}

Keterangan:

* : Hasil bagi dari ketelitian alat $(0,001)$ dibagi 2.

SD: Standar Deviasi

Tabel diatas merupakan konsentrasi fenol, kromium dan minyak yang terdapat di dalam air Sungai Bremi Kabupaten Pekalongan berdasarkan ruang (spasial) dan waktu (temporal). Konsentrasi fenol yang terdapat pada air Sungai Bremi Kabupaten Pekalongan pada bulan Mei dan Juni berkisar antara 0-0,031 mg/l. Konsentrasi kromium heksavalen Cr (VI) yang teradpat pada air Sungai Bremi Kabupaten Pekalongan yaitu $0,0005 \mathrm{mg} / \mathrm{l}$. Konsentrasi minyak pada air Sungai Bremi Kabupaten Pekalongan pada bulan Mei dan Juni dan bulan Juni berkisar antara 3,6-23,6 mg/l.

\section{Sebaran Spasial dan Temporal Fenol, Kromium dan Minyak}

a. Sebaran Spasial dan Temporal Fenol pada bulan Mei-Juni 2013

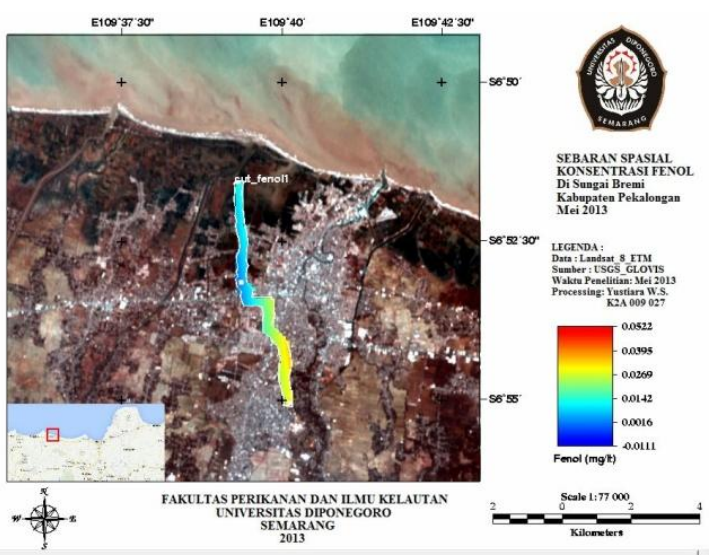

Gambar 1. Sebaran Spasial Fenol (mg/l) di sekitar Sentra Industri Batik dalam air Sungai Bremi Kabupaten Pekalongan Bulan Mei 2013

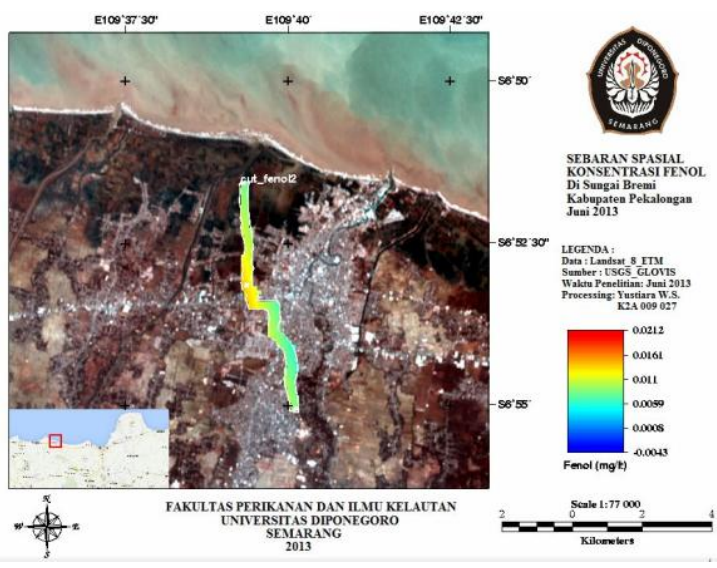

Gambar 2. Sebaran Spasial Fenol (mg/l) di sekitar Sentra Industri Batik dalam air Sungai Bremi Kabupaten Pekalongan Bulan Juni 2013

Gambar 1. dan Gambar 2. di atas menunjukkan sebaran fenol berdasarkan data spasial dan data temporal. Sebaran data spasial terlihat pada gradasi warna dengan skala nilai berdasarkan dari hasil pengujian sampel air di laboratorium, sedangkan data temporal dilihat pada perbedaan waktu pengambilan sampel. 
b. Sebaran Spasial dan Temporal Minyak pada bulan Mei-Juni 2013
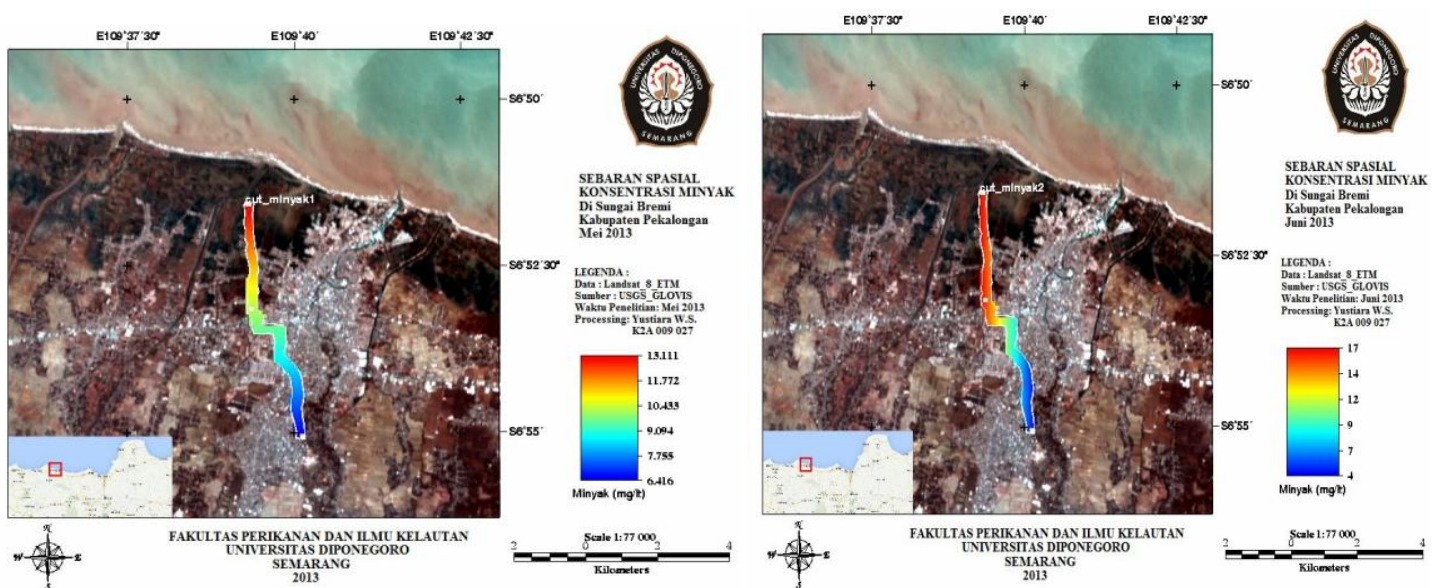

Gambar 3. Sebaran Spasial Minyak (mg/l) di sekitar Sentra Industri Batik dalam air Sungai Bremi Kabupaten Pekalongan Bulan Mei 2013

Gambar 4. Sebaran Spasial Minyak (mg/l) di sekitar Sentra Industri Batik dalam air Sungai Bremi Kabupaten Pekalongan Bulan Juni 2013

Sama hal-nya dengan sebaran fenol, Gambar 3. dan Gambar 4. di atas menunjukkan sebaran minyak berdasarkan data spasial dan data temporal. Sebaran data spasial terlihat pada gradasi warna dengan skala nilai nya berdasarkan hasil dari pengujian sampel air di laboratorium, sedangkan data temporal dilihat pada perbedaan waktu pengambilan sampel.

Parameter kualitas air

Tabel 3. Data Kelimpahan dan Indeks Biologi Fitoplankton di Sungai Bremi

\begin{tabular}{cccccccccccccc}
\hline St & Spl & A & SD & B & SD & C & SD & D & SD & E & SD & F & SD \\
\hline \multirow{1}{1}{} & $\mathbf{1}$ & 26,8 & 0,265 & 27,3 & 0,577 & 0.0223 & 0.006 & 4,7 & 0.3 & 2 & 0,6 & 24,5 & 2,8 \\
& $\mathbf{2}$ & 26,8 & 0,208 & 28 & 0 & 0.0186 & 0.002 & 4,5 & 0,3 & 1,6 & 0,6 & 28,6 & 2,08 \\
& $\mathbf{1}$ & 30,8 & 0,416 & 32 & 0 & 0.0459 & 0.023 & 3,4 & 0,4 & 2 & 0,6 & 12,1 & 5,9 \\
$\mathbf{2}$ & $\mathbf{2}$ & 30,6 & 0,781 & 31,3 & 0,577 & 0.0495 & 0.005 & 4,5 & 0.3 & 3 & 0,2 & 18 & 4 \\
& $\mathbf{1}$ & 30,2 & 0,208 & 31 & 0 & 0.0633 & 0.032 & 3,5 & 0,2 & 2,3 & 0,1 & 20 & 1,5 \\
$\mathbf{3}$ & $\mathbf{2}$ & 30,6 & 0,781 & 31 & 0 & 0.0843 & 0.026 & 4,1 & 0,1 & 2,1 & 0,1 & 15 & 3,04 \\
\hline
\end{tabular}

Keterangan:

St : Stasiun

Spl : Sampling

A : Temperatur Air $\left({ }^{\circ} \mathrm{C}\right)$

B : Temperatur Udara $\left({ }^{\circ} \mathrm{C}\right)$

C : Arus $(\mathrm{m} / \mathrm{s})$

$\mathrm{D}: \mathrm{pH}$

E : DO $(\mathrm{mg} / \mathrm{l})$

F : kecerahan $(\mathrm{m})$

SD : Standar deviasi

Berdasarkan tabel di atas dapat dilihat bahwa temperatur pada bulan Mei dan bulan Juni tidak jauh berbeda. Temperatur air pada bulan Mei berkisar antara 26,8-30,8 $\mathrm{C}$, temperatur tertinggi berada pada stasiun 2 dengan nilai $30,8^{\circ} \mathrm{C}$. Temperatur air bulan Juni berkisar antara 26,8-30,6 $6^{\circ} \mathrm{C}$, dengan temperatur tertinggi pada stasiun 2 dan stasiun 3. Rata-rata temperatur udara pada bulan Mei berkisar antara $27,3-32^{\circ} \mathrm{C}$, temperatur udara tertinggi pada stasiun 2 yaitu $32^{\circ} \mathrm{C}$. Rata-rata temperatur udara bulan Juni berkisar antara $28-31,3^{\circ} \mathrm{C}$ dengan temperatur tertinggi pada stasiun 2 dengan nilai $31,3^{\circ} \mathrm{C}$. Temperatur air, pada bulan Mei dan Juni tidak mengalami kenaikan temperatur yang tajam, begitu pula dengan temperatur udara. Arus pada bulan Mei berkisar antara 0,0223-0,0633 m/s, dengan kecepatan arus tertinggi pada stasiun 3. Kecepatan arus bulan Juni berkisar antara $0.002-0.0843 \mathrm{~m} / \mathrm{s}$ dengan arus tertinggi pada stasiun 3. Nilai $\mathrm{pH}$ pada bulan Mei berkisar antara 3,42-4,69 dan bulan Juni berkisar antara 4,11-4,48. Nilai DO pada bulan Mei berkisar antara 1,55-1,92 mg/l dan pada bulan Juni berkisar antara 2,15-2,96 mg/l. Kecerahan air Sungai Bremi pada bulan Mei berkisar antara 12,08-24,5 dan pada bulan Juni kecerahan air Sungai Bremi berkisar antara 15-28,6. 


\section{Pembahasan}

Fenol

Menurut Effendi (2003), senyawa fenol $\left(\mathrm{C}_{6} \mathrm{H}_{5} \mathrm{OH}\right)$ terdiri dari kresol, xilenol, klorofenol, katekol, hidroquinon, timol, naftol dan lain sebagainya. Senyawa fenol dihasilkan dari proses pemurnian minyak, industri kimia, tekstil, plastik dan lain sebagainya. Penelitian ini dilakukan untuk melihat konsentrasi fenol dalam perairan Sungai Bremi yang telah tercemari limbah zat pewarna tekstil dari batik.

Hasil uji laboraturium pada bulan Mei nilai fenol Sungai Bremi berkisar antara 0-0,031 mg/l sedangkan pada bulan Juni nilai fenol berkisar antara 0-0,027 mg/l. Berdasarkan PP No. 82 Tahun 2001 nilai tertinggi fenol pada bulan Mei di stasiun sebesar $0,031 \mathrm{mg} / \mathrm{l}$ telah melebihi ambang batas untuk kualitas air. Menurut PP No. 82 tahun 2001, batas maksimal fenol untuk perairan air tawar sebesar 0,01 mg/l.

Berdasarkan Gambar 1. Dan Gambar 2. di atas dapat dilihat bahwa sebaran fenol berdasarkan ruang dan waktu. Berdasarkan sebaran spasial dan temporalnya nilai fenol tertinggi bulan Mei berada pada stasiun 1, sedangkan konsentrasi fenol pada stasiun 1 di bulan Juni mengalami penurunan menjadi 0,003 $\mathrm{mg} / \mathrm{l}$. Konsentrasi tertinggi fenol bulan Juni berada pada stasiun 2, dimana stasiun 2 merupakan daerah yang diduga sebagai daerah sumber pencemar karena terdapat beberapa pabrik batik dan disepanjang aliran sungai terdapat pemukiman warga yang juga merupakan buruh batik colet. Berbeda dengan bulan Juni, konsentrasi fenol pada stasiun 2 bulan Mei sebarannya lebih rendah. Sebaran fenol pada bulan Mei dan Juni di stasiun 3 cenderung hampir sama.

Tingginya fenol pada bulan Mei stasiun 1 dikarenakan pada daerah stasiun 1 terdapat industri batik printing dan pencucian atau pembilasan batik langsung ke dalam aliran sungai, sedangkan bulan Juni mengalami penurunan karena pada pengambilan sampel air dilakukan pada hari Jum'at, dimana pada hari Jum'at warga sekitar tidak melakukan kegiatan membatik maupun membuang limbah. Rendahnya konsentrasi fenol pada stasiun 2 diduga karena sebagian senyawanya telah terdegradasi oleh mikroorganisme. Pada stasiun 2 nilai BOD tinggi, menanandakan bahwa adanya aktivitas mikroorganisme menguraikan bahan organik. Menurut Dewilda (2012), senyawa Fenol merupakan senyawa yang dapat menimbulkan bau tidak sedap, bersifat racun dan korosif terhadap kulit (iritasi). Fenol sederhana seperti phenol, cresol dan xylenol mudah larut dalam air dan lebih mudah didegradasi oleh mikroorganisme pengurai fenol.

Menurut Sunarto (2004), fenol yang terdapat dalam limbah cair batik sendiri berasal dari pelunturan lilin dan pelorodan malam yang menempel pada kain. Selain dari limbah batik, fenol dapat berasal dari limbah domestik dan rumah tangga.

\section{Kromium}

Kromium termasuk dalam logam berat yang digunakan untuk pembuatan zat pewarna sintetis. Penelitian ini betujuan untuk melihat sebaran serta konsentrasi kromium heksavalen yang lebih berbahaya daripada kromium trivalen.

Pada Tabel 2. di atas dapat dilihat bahwa nilai kromium heksavalen pada semua titik bernilai $0,0005 \mathrm{mg} / \mathrm{l}$, yang dimaksud adalah konsentrasi kromium heksavalen yang terdapat dalam perairan tersebut kurang dari $0,003 \mathrm{mg} / \mathrm{l}$. Karena rendahnya nilai kromium yang terdapat dalam sampel air sungai tersebut, mengakibatkan jumlah konsentrasi kromium heksavalen tidak dapat terbaca oleh alat. Nilai 0,0005 mg/l sendiri didapat dari hasil bagi dari nilai ketelitian alat dibagi 2. Batas minimum kromium yang dapat dibaca oleh alat sebesar $0,003 \mathrm{mg} / \mathrm{l}$.

Berdasarkan hasil laboratorium kromium heksavalen memiliki nilai yang sama setiap titiknya pada bulan Mei dan kedua. Hal ini dikarenakan pada saat pengujian laboratorium konsentrasi kromium heksavalen di perairan Sungai Bremi sedikit jumlahnya dan nilainya dibawah dari ketelitian alat yaitu 0,003 mg/l sehingga nilai kromium heksavalen tidak dapat terbaca oleh alat. Sebaran spasial dan temporal dari kromium dikatakan konstan atau tetep, karena meliki nilai yang sama pada setiap titiknya.

Rendahnya nilai kromium bisa juga disebabkan karena sebagian besar kromium mengendap dalam sedimen. Menurut Erlangga (2007), limbah dari aktifitas pabrik yang membuang limbah cairnya ke sungai umumnya berupa limbah cair yang mengandung logam berat. Diketahui bahwa sifat logam berat mudah mengendap di dasar perairan dan berkaitan dengan komponen kimia lainnya, sehingga kemungkinan terjadinya pengakumulasian logam berat tersebut di dasar perairan juga menjadi lebih besar.

Menurut Sasongko (2010), konsentrasi unsur logam yang terlarut dalam air dipengaruhi juga oleh musim. Adanya perbedaan musim berpengaruh terdapat konsentrasi logam terlarut. Kandungan logam berat pada musim hujan akan lebih kecil karena proses pengenceran, sedangkan pada musim kemarau komsentrasi logam berat lebih tinggi. Berkaitan dengan musim kondisi badan air di aliran Sungai Bremi lebih dipengaruhi oleh kegiatan produksi dari industri batik yang baynak dilakukan pada musim kemarau.

Rendahnya konsentrasi kromium heksavalen bisa disebabkan karena rendahnya nilai $\mathrm{pH}$ pada air Sungai Bremi. Perairan Sungai Bremi ini digolongkan dalam perairan asam, karena $\mathrm{pH}$ airnya berkisar antara 3,13-4,92. Menurut Asdak (2007), perairan yang nilai $\mathrm{pH}$ kurang dari 4,8 dan lebih dari 9,2 termasuk perairan asam dan tercemar. $\mathrm{pH}$ asam dapat memudahkan reaksi kimia pada logam berat untuk menjadi ion- 
ion, selain itu proses reduksi senyawa kromium heksavalen menjadi kromium trivalen dapat berlangsung pada perairan yang sangat asam (Palar, 2008).

\section{Minyak}

Minyak dan lemak banyak terdapat dalam buangan limbah, baik domestik maupun limbah batik. Minyak yang terdapat dalam limbah batik ini berasal dari malam yang telah dilelehkan pada proses pembuatan rintang batik. Menurut Sunarto (2004), minyak dan lemak dihasilkan dari proses pencucian batik, untuk menghilangkan malam dengan air panas. Konsentrasi nilai minyak pada bulan Mei berkisar antara 5,2$16,8 \mathrm{mg} / \mathrm{l}$ sedangkan pada bulan Juni berkisar antara 3,6-23,6 mg/l.

Berdasarkan baku mutu PP No.82 Tahun 2001 konsentrasi minyak pada Sungai Bremi bulan Mei dan Juni telah melampaui ambang batas, dengan batas maksimal minyak sebesar $1 \mathrm{mg} / \mathrm{l}$. Menurut Effendi (2003), kadar minyak yang melebihi $0,3 \mathrm{mg} / \mathrm{l}$ akan bersifat toksik terhadap perairan.

Berdasarkan gambar di atas, dapat dilihat sebaran minyak berdasarkan tempat dan waktu yang berbeda. Konsentrasi minyak tertinggi bulan Mei dan Juni berada pada stasiun 3. Sebaran minyak dari stasiun1 sampai stasiun 3 bulan Juni konsentrasinya lebih tinggi daripada bulan Mei. Tingginya kadar minyak ini bisa diakrenakan adanya aliran limbah batik dari stasiun 1 dan 2 yang merupakan sentra industri batik dan domestik dari pemukiman sepanjang sungai, sedangkan stasiun 3 ini dekat dengan muara dan jalur lewat kapal nelayan melaut. Kemungkinan konsentrasi minyak tinggi dikarenakan adanya kebocoran dari bahan bakar kapal nelayan yang melalui stasiun 3 .

\section{KESIMPULAN}

Kesimpulan yang didapat dari penelitian ini antara lain :

1. Konsentrasi fenol Sungai Bremi bulan Mei dan Juni 2013 berkisar antara 0-0,031 mg/l, konsentrasi kromium 0,0005 mg/l pada bulan Mei dan Juni 2013 sedangkan konsentrasi minyak bulan Mei dan Juni 2013 berkisar antara 3,6-23,6 mg/l.

2. Sebaran fenol tertinggi secara spasial berada pada stasiun 1 dan secara temporal berada pada bulan Mei, sedangkan sebaran spasial dan temporal fenol tertinggi bulan Juni berada pada stasiun 2. Sebaran tertinggi minyak secara spasial berada pada stasiun 3 , sebaran tertinggi minyak secara temporal berada pada bulan Mei dan Juni. Sebaran spasial dan temporal dikatakan konstan atau tidak bisa dibaca sebarannya karena konsentrasi kromium tiap titiknya sama.

\section{UCAPAN TERIMA KASIH}

Ucapan terima kasih ditujukan kepada kepada Dr. Ir. Haeruddin, M.Si dan Dr. Ir. Frida Purwanti, M.Sc atas bimbingannya dalam penyusunan jurnal ini.

\section{DAFTAR PUSTAKA}

Arikunto. 2006. Prosedur Penelitian Suatu Pendekatan Praktik, Edisi Revisi VI. Rineka Cipta. Jakarta.

Asdak, C. 2002. Hidrologi dan Pengelolaan Daerah Sungai. Gajah Mada University Press. Yogyakarta.

Dewilda. 2012. Degradasi Fenol Oleh Mikroorganisme Laut. Jurusan Teknik Lingkungan Universitas Andalas. J. Tek. Ling, 9(1):59-73.

Effendi, H. 2003.Telaah Kualitas Air Bagi Pengelolaan Sumberdaya dan Lingkungan Perairan. Penerbit Kanisius. Yogyakarta.

Erlangga. 2007. Efek Pencemaran Perairan Sungai Kampar di Provinsi Riau terhadap Ikan Baung (Hemibragus nemurus). [Skripsi]. Institut Pertanian Bogor. Bogor.

Haidi, A. 2005.Prinsip Pengelolaan Pengambilan Sampel Lingkungan. PT. Gramedia Pustaka Utama Jakarta. Palar, H. 2008.Pencemaran dan Toksikologi Logam Berat. Rineka Cipta. Jakarta.

PP No. 82 Tahun 2001. Pengelolaan Kualitas Air dan Pengendalian Pencemaran Air.

Sasongko, D. dan W. Panji Tresna. 2010. Identifikasi Unsur dan Kadar Logam Berat pada Limbah Pewarna Batik dengan Metode Analisis Pengaktifan Neutron. J. Ilmu Pengetahuan dan Teknologi Telaah, 2(1):22-27

Suharto. 2001. Limbah Kimia dalam Pencemaran Udara dan Air. Penerbit Andi. Yogyakarta.

Sunarto. 2004. Toksisitas Akut Limbah Cair Pabrik Batik CV. Giyant Santoso Surakarta dan Efek Sublethalnya terhadap Struktur Mikro Anatomi Branchia dan Herper Ikan Nila (Orechromis Niloticus T.). Universitas Sebelas Maret, Surakarta. J. Bio. Smart. 6(2):147-153.

Ulya, A. 2012. Pengaruh Variasi pH dan Suhu Terhadap Kemampuan Degradasi Fenol dan Pertumbuhan Bakteri Pendegradasi Fenol dari Limbah Cair Tekstil. [Skripsi]. Universitas Islam Negeri Sunan Kalijaga. Yogyakarta.

Wardhana, W.A. 2004. Dampak Pencemaran Lingkungan. Penerbit Andi. Yogyakarta. 